\title{
A review of starch digestion in the lactating dairy cow and proposals for a mechanistic model: 2 . Postruminal starch digestion and small intestinal glucose absorption
}

\author{
J.A.N. Mills ${ }^{1}$, J. France' ${ }^{1}$ and J. Dijkstra ${ }^{2}$ \\ 'The University of Reading, Centre for Dairy Research, \\ Department of Agriculture \\ Earley Gate, PO Box 236, Reading RG6 6AT, UK \\ ${ }^{2}$ WIAS Animal Nutrition, Wageningen Agricultural University \\ Marijkeweg 40, PO Box 338, 6700 AH Wageningen. The Netherlands
}

(Received 16 July 1999; accepted 7 October 1999)

\section{ABSTRACT}

The objective of this paper is to review the literature concerning postruminal starch digestion and glucose absorption in the lactating dairy cow and to propose the framework for a mechanistic model representing these processes. Postruminal starch digestion is of particular importance where high levels of rumen escape starch flow from the rumen. However, the digestion of starch and absorption of the resulting glucose within the small intestine may be limited by pancreatic secretion of $\alpha$-amylase and the distribution of SGLT1 glucose transporters respectively. During the investigation, use is made of data gathered from both in vivo and in vitro studies concerning mainly lactating dairy cows. The relative importance of ruminal and postruminal starch digestion is discussed along with the significance of dietary starch source and processing method as factors affecting postruminal starch digestion. Postruminal starch digestion and intestinal glucose uptake becomes increasingly important at high starch intakes. Other factors influencing the nature of starch digestion are also presented in order to allow the interpretation of experimental data and hence the development of a conceptual model of starch digestion. The review subsequently examines postruminal starch digestion as it is represented in extant models of ruminant digestion and discusses the essential elements of a digestion model that would have the required capability to accurately account for the fate of rumen escape starch in a range of practical feeding situations. Whilst the digestion of starch within the rumen is well represented in several working models presented in the literature, postruminal starch digestion and glucose uptake has been largely ignored. Finally, a proposed framework is presented as a scheme upon which a future model of starch digestion in the dairy cow may be built.

KEY WORDS: starch, glucose, digestion, absorption, model, dairy cow, postruminal 


\section{INTRODUCTION}

Current methods of feed evaluation for dairy cows are too imprecise to meet the demands of today's dairy farmer. There is a requirement for increased production efficiency in order to maintain financial margins at lower product prices. High genetic merit cows are capable of high milk yields, however the performance of these cows varies widely depending on nutritional inputs. In particular, the trend towards maximising the energy density of diets and hence the feeding of high starch feedstuffs has highlighted the variation in milk production between apparently isoenergetic diets. Both dietary starch concentration and starch type affects the milk yield and composition. There has also been debate as to the merit of rumen escape starch and the potential energetic benefits that may exist where glucose is absorbed directly from the small intestine, avoiding rumen fermentation and associated heat energy losses. The prospect of influencing plasma glucose concentrations via the small intestinal digestion of starch and uptake of the glucose from the intestinal lumen has implications for mammary glucose supply and therefore milk yield. Employing dynamic mechanistic modelling techniques to utilise existing experimental data and develop systems that are better able to predict lactational performance than current empirical schemes is seen by many (Beever et al., 1991; Baldwin, 1995; AFRC, 1999) as the necessary approach to developing more appropriate feed evaluation schemes. Part 1 of this review (Mills et al., 1999) discussed the representation of the rumen within such a mechanistic scheme to account for starch in the diet. On many high starch diets the contribution of postruminal digestion to total tract starch digestion is significant and occasionally more than that of digestion within the rumen itself. Therefore a mechanistic approach to postruminal digestion is vital to the success of any model that attempts to predict the fate of ingested starch within the lactating dairy cow.

\section{Objectives}

The first objective of this paper is to review the literature relating to the postruminal digestion of starch and absorption of glucose resulting from the digestion of starch in the small intestine of the lactating dairy cow. This will allow characterisation and quantification of the factors affecting the site, rate and extent of starch digestion and glucose uptake. The second objective is to identify a suitable framework for a dynamic mechanistic model of postruminal starch digestion and small intestinal glucose absorption.

\section{Starch digestion data from lactating dairy cows}

In order to achieve the objectives of this study, starch digestion data from $22 \mathrm{in}$ vivo experiments involving lactating dairy cattle have been summarised in the 
appendix of Part 1 of this review and certain elements of these data are presented throughout. In situ and in vitro data concerning the degradation of dietary starch within the rumen and intestines have also been presented.

\section{POSTRUMINAL STARCH DIGESTION AND GLUCOSE ABSORPTION}

From the 15 studies in the appendix of Part 1 of this review (Mills et al., 1999) that measured the proportion of starch escaping rumen degradation, the mean quantity digested in both the small and large intestines was $2.4 \mathrm{~kg}$ day $^{-1}$. The data demonstrated a considerable potential for postruminal starch digestion with the maximum amount digested being $5.1 \mathrm{~kg} \mathrm{day}^{-1}$ (McCarthy et al., 1989). Figure 1 clearly shows how postruminal starch digestion increases as the passage of starch to the duodenum increases, with no obvious limit to the amount of postruminal starch digestion. This confirms the relationship described by Reynolds et al. (1997).

\section{Starch digestion in the small intestine}

Starch undegraded in the rumen, together with microbial starch, passes to lower regions of the digestive tract. Starch associated with the protozoa is not washed out of the rumen at the same rate as the other microbes, due to the selective retention of these protozoa. Therefore the concentration of starch in the microbial outflow from the rumen would be considerably less than that of the microbial population within the rumen, due to the relatively high storage polysaccharide content of the protozoa (Czerkawski, 1978). Faichney (1989) suggested that the fractional outflow rate of protozoa was 0.45 of the fractional passage rate of solid material from the rumen. However, the contribution of protozoa to the nutrition of the cow remains uncertain (Williams and Coleman, 1997).

The capacity for the enzymatic hydrolysis of starch entering the small intestine is important especially where high starch intakes lead to significant quantities of starch escaping fermentation in the rumen. The pancreas secretes $\alpha$-amylase which hydrolyses starch to produce limit dextrins and linear oligosaccharides of two or three glucose units (Gray, 1992; Harmon, 1993). The proportion of starch entering the small intestine that is degraded depends on enzymic activity, starch source, passage rate and particle size of the digesta. Kreikemeier et al. (1990) demonstrated a $50 \%$ increase in pancreatic $\alpha$-amylase activity as dietary energy intake increased from one to two times maintenance in 7-month-old calves. In the same study, where energy intakes were similar, starchy diets tended to decrease pancreatic $\alpha$-amylase secretion when compared to forage based rations. Russell et al. (1981) obtained similar results for Holstcin steers fed either lucerne hay or maizebased diets. Furthermore Russell et al. (1981) observed no increase in pancreatic 

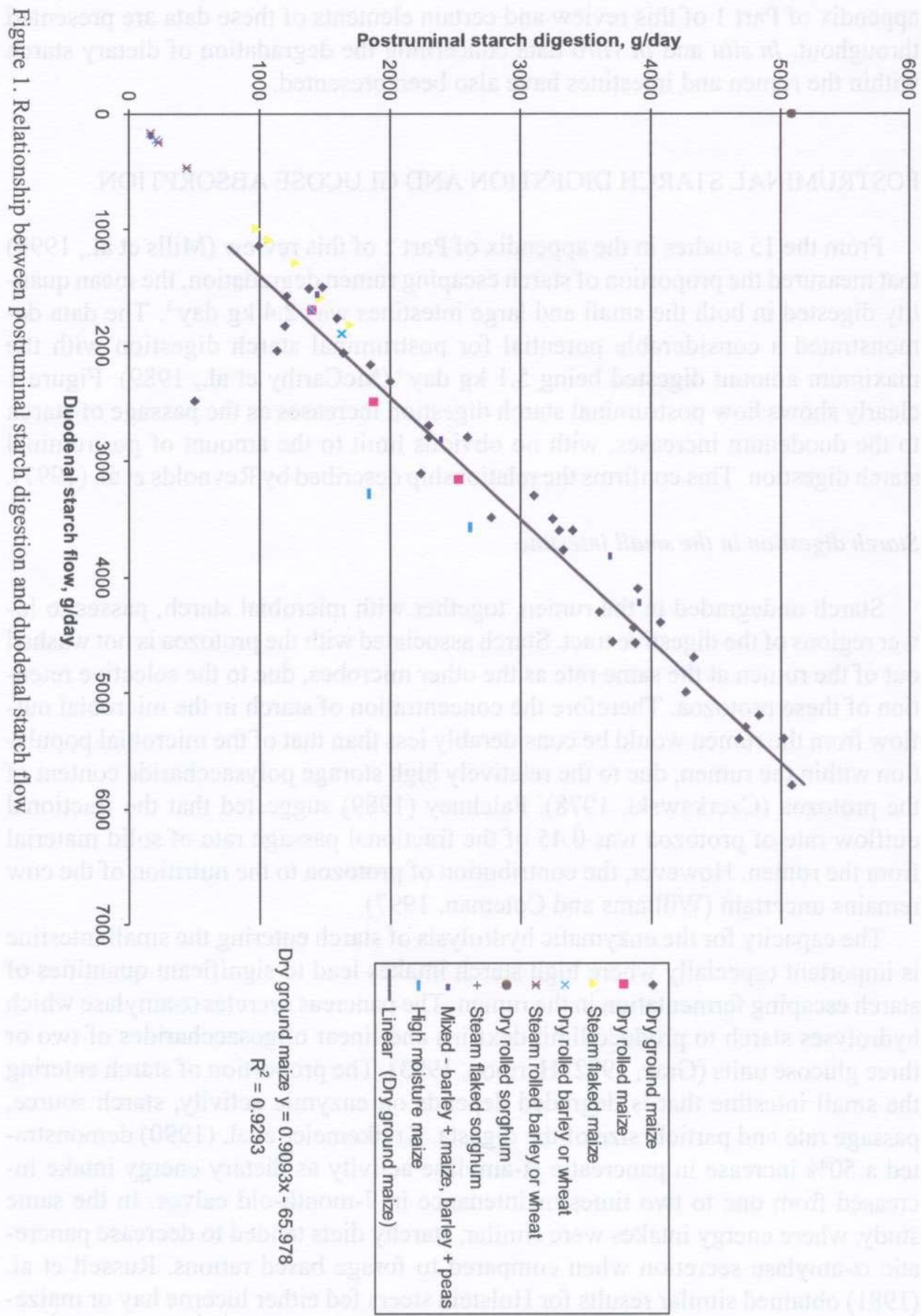
$\alpha$-amylase concentration as energy intake was increased from 2 to 3 times maintenance. Chittenden et al. (1984) also demonstrated a decrease in pancreatic $\alpha$-amylase secretion in wethers administered with duodenal starch infusions. The biochemical basis for the regulation of the small intestinal digestive enzymes is not entirely clear, especially regarding the effects observed following the feeding of starch. However plasma glucose, duodenal propionate and plasma insulin concentrations have been implicated as causes of possible negative feedback mechanisms for pancreatic $\alpha$-amylase secretion (Call et al., 1975; Johnson et al., 1986; Kreikemeier et al., 1990). Whilst it is likely that plasma glucose and insulin influence $\alpha$-amylase secretion in the dairy cow, specific information regarding their interrelationship is lacking. Call et al. (1975) described decreasing $\alpha$-amylase secretion with jugular infusions of glucose. Intravenous VFA infusion has produced increases in pancreatic $\alpha$-amylase secretion in sheep (Kato et al., 1989). Johnson et al. (1986) infused propionate into the duodenum of sheep and reported an initial increase in $\alpha$-amylase activity followed by a decline.

As feed intake increases, the level of pancreatic secretion also increases. Fushiki and Iwai (1989) presented an explanation for this occurrence involving the inactivation of pancreatic cholecystekinin (CCK) releasing peptide by trypsin and chemotrypsin. Feed protein entering the duodenum and binding with the trypsin and chemotrypsin facilitates the interaction of CCK releasing peptide with the receptors on the intestinal brush border membrane. The subsequent CCK release stimulates the pancreatic secretions. The influence of dietary protein on starch digestion will be discussed later.

Walker and Harmon (1995) investigated the influence of abomasal starch infusion on pancreatic exocrine secretion in Holstein steers. They confirmed the studies of Kreikemeier et al. (1990) and Russell et al. (1981) indicating that an increase in dietary energy intake causes a rise in $\alpha$-amylase secretion. Pancreatic $\alpha$-amylase concentration was decreased in response to abomasal infusion of starch hydrolysate. Walker and Harmon (1995) suggest a regulatory mechanism involving one or more of the peptides; peptide YY, pancreatic polypeptide or somatostatin, for the reduction in $\alpha$-amylase concentration. As increased levels of these peptides are secreted with elevated duodenal starch flow, pancreatic exocrine secretion is inhibited. It is also possible that the increase in plasma glucose resulting from high levels of intestinal starch digestion and glucose absorption causes a decline in pancreatic secretory activity.

Degradation of the limit dextrins and linear oligosaccharides occurs via surface oligosaccharidases, located on the brush border membrane of the intestinal microvilli. Oligosaccharides are large glycoproteins that are synthesised within the enterocytes and are transferred to the brush border surface. They remain attached by a short terminal hydrophobic section of the protein chains. This allows the active catalytic sites of the oligosaccharidases to be free at the interface of the enterocyte 
and the intestinal lumen. Maltase and isomaltase activity leads to the production of glucose for absorption across the intestinal wall by both passive and active transport. There is no active transport process in the intestinal enterocyte that can accommodate anything larger than free glucose. Research with non-ruminants suggests that a high degree of efficiency is possible in the absorption of glucose derived from intestinally digested starch particularly in comparison to free glucose (Jones et al., 1983). The reason for this efficiency may be that the oligosaccharide cleavage at the brush border membrane creates a region of high glucose concentration favourable to transport into the enterocyte (Gray, 1992).

Kreikemeier et al. (1990) showed that the degradation of starch throughout the small intestine of calves was dependent upon the distribution of amylolytic enzymes. The activity of both maltase and isomaltase per $\mathrm{cm}$ of intestine was lowest in the duodenum and highest in the mid jejunum and ileum $(\mathrm{P}<0.05)$. Russell et al. (1981) found no difference in maltase activity of steers fed lucerne hay or maizebased diets at 1 or 2 times maintenance energy requirement. Maltase activity was highest in the jejunum and declined towards the ileum. This distribution was also noted in sheep (Janes et al., 1985). Janes et al. (1985) demonstrated an elevated hydrolysis of maltose and isomaltose for sheep fed a maize-based diet in comparison to one of dried grass. Whether this effect resulted from increased ME intake or dietary composition was unclear. Data from Kreikemeier et al. (1990) suggests limited effects of both dietary composition and ME intake. Using the data of Kreikemeier et al. (1990), Harmon (1992) proposed that the influence of ME intake on intestinal oligosaccharidase activity was the direct result of changes in intestinal length. Small intestinal length of calves fed either forage or grain based diets was significantly increased at intakes of twice the net energy for maintenance in comparison to calves fed only at maintenance (Kreikemeier et al., 1990).

Huntington (1997) concluded that the review by Owens et al. (1986), the results of Kreikemeier et al. (1991) and his own simulations showed that $\alpha$-amylase is more limiting than intestinal oligosaccharidase activity in the degradation of starch to glucose. Owens et al. (1986) concluded that both inadequate enzymic secretion and the large particle size of the digesta could limit the proportion of starch entering the small intestine that was subsequently digested. Walker et al. (1994) attempted unsuccessfully to increase pancreatic $\alpha$-amylase secretion via the use of slaframine. Although total pancreatic secretions increased, the concentration of $\alpha$-amylase was reduced.

\section{In vitro determination of small intestinal starch degradation}

Modelling the degradation of starch by enzymes in the small intestine relies on estimates of the degradation and passage rates through the small intestine. In vitro estimates of starch degradation rate relating to the small intestine have proved to 
be unreliable during a previous modelling attempt (Ewing and Johnson, 1987). Data is available relating to incubations with the appropriate enzymes such as those found in pancreatin (Cone et al., 1989; Cone, 1991) or intestinal mucosa extractions (Coombe and Siddons, 1973). However, problems arise when these values are applied to starch degradation as it occurs in the small intestine. The starch used in the majority of these incubations has not been exposed to prior incubations with rumen fluid or acidic conditions mimicking the abomasum. Therefore most of the published in vitro experiments seem to be better suited to predicting the rate of starch degradation following duodenal infusion studies. Further investigation is required into the degradation of different starch types, processed differently for incubations that more accurately reflect small intestinal digestion. In the meantime, current in vitro estimates should be used with caution and the correction of these values may be necessary to allow the proper functioning of a mechanistic model (Ewing and Johnson, 1987).

\section{Small intestinal glucose absorption}

Even when starch in the small intestine is completely degraded the capacity for the absorption of the resulting glucose may be limited (Kreikemeier et al., 1991). Glucose absorption can be classified as two distinct processes based upon energy expenditure. Passive diffusion of glucose from the intestinal lumen along a favourable concentration gradient involves no energetic cost. This may occur either as paracellular movement of glucose from the intestinal lumen (Pappenheimer and Reiss, 1987) or via facilitated glucose transporters (GLUT2) in the basolateral membranes of the enterocyte. Although glucose transport by GLUT2 facilitates removal of glucose from the enterocyte, if glucose concentration is lower in the cell than in the blood, GLUT2 will enable glucose entry into the enterocyte. Active uptake of glucose by $\mathrm{Na}^{+}$dependent glucose transporters (SGLT's) is the other mechanism by which glucose can be removed from the intestinal lumen and into the enterocyte. The SGLT found in the intestinal tissue of dairy cows is SGLT1 (Shirazi-Beechey et al., 1995).

Glucose transport activity can be best described by the model involving a single membrane carrier and a passive diffusion component and is described mathematically by Meddings and Westergaard (1989). Table 1 summarises the apparent in vivo and in vitro $\mathrm{K}_{\mathrm{m}}$ values for glucose transport in the small intestine of several species. Most of the in vitro data are derived from the use of brush border membrane vesicles. For a discussion of this technique the reader is referred to Bauer (1996). However Okine et al. (1994) used flat duodenal sheets with glucose evoked electrical potentials to examine the SGLT1 activity. The results are not corrected for the effects of unstirred water layers at the luminal surface. Indeed, the difference between the in vivo and in vitro values (obtained with membrane vesicles) 


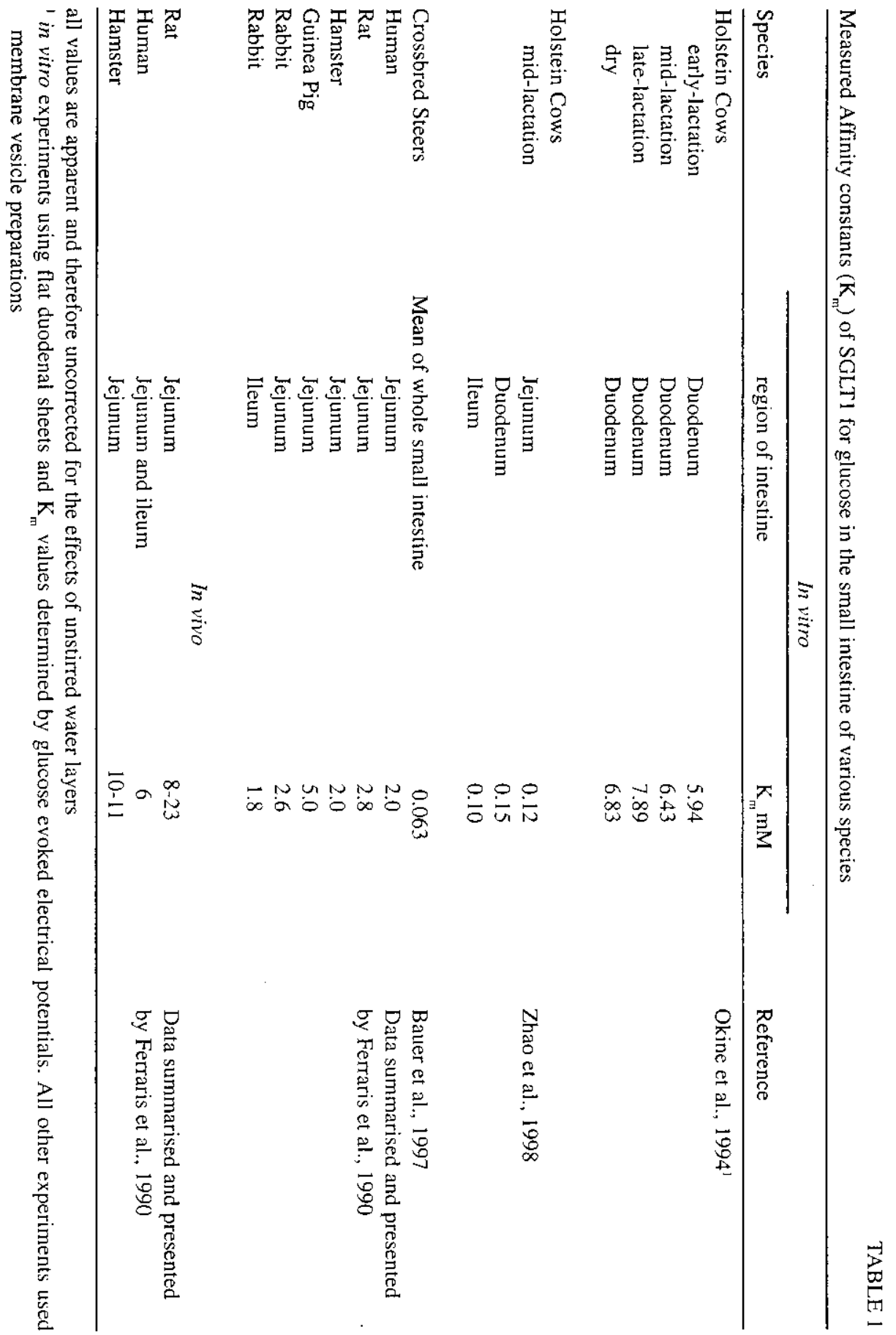


can be explained by the existence of thicker unstirred layers in vivo (Thomson, 1979; Barry and Diamond, 1984; Meddings and Westergaard, 1989). These unstirred layers provide resistance to glucose transport and this leads to an overestimation of the affinity constant of SGLT1 for glucose. Meddings and Westergaard (1989) showed the apparent $\mathrm{K}_{\mathrm{m}}$ values for in vivo D-glucose transport in rat jejunum to be $13.7 \mathrm{mmol} / \mathrm{l}$ whereas the corrected constant was between 0.8 and $1.8 \mathrm{mmol} / \mathrm{l}$ depending on the method used to derive the constant. The $\mathrm{K}_{\mathrm{m}}$ for the basolateral sodium independent transporter (GLUT2) in isolated vesicles is in the range of 40-50 mmol/1 (Maenz and Cheeseman, 1987). This led Meddings and Westergaard (1989) to conclude that movement of glucose across the microvillus membrane is the rate-limiting step in intestinal glucose absorption. However lower estimates of the affinity constant for GLUT2 of approximately $20 \mathrm{mmol} / \mathrm{l}$ are available (Thorens, 1993). It should be noted that the derivation of these kinetic constants has involved experiments concerned with intestinal glucose infusions. Where intestinal starch is involved, the localised high concentration of luminal glucose within the unstirred water layer surrounding oligosaccharidases on the brush border (Gray, 1992), may be more significant than mean luminal glucose concentration in affecting glucose transport.

Whilst SGLT1 is present on the brush border membrane of the enterocytes, the $\mathrm{Na}^{+} \mathrm{K}^{+}$ATPase is present on the basolateral membrane and pumps $\mathrm{Na}^{+}$out of the enterocyte, maintaining an inwardly directed $\mathrm{Na}^{+}$electrochemical gradient. This sodium dependent transport is based on a stoichiometry of two sodium molecules cotransported with one glucose molecule. Assuming three $\mathrm{Na}^{+}$and two $\mathrm{K}^{+}$countertransported per ATP hydrolysed, a stoichiometry of three glucose molecules transported per two ATP hydolysed in the enterocyte exists. Since five ATP are synthesised per $\mathrm{O}_{2}$ molecule consumed (Gill et al., 1989) 15 glucose molecules are transported per two $\mathrm{O}_{2}$ molecules consumed. The distribution of SGLT1 in the small intestine may vary between species (Ferraris et al., 1989; Zhao et al., 1998). Krehbiel et al. (1996) indicate that glucose absorption in the distal small intestine is limited by glucose transporter activity. The consequence of a lack of synchrony between site of starch digestion and glucose absorption is an accumulation of intestinal glucose. This results in a negative feedback on the activity of disaccharidases and eventually on $\alpha$-amylase activity. Therefore some glucose along with disaccharides and oligosaccharides may pass from the small intestine for subsequent fermentation in the large intestine.

The significance of paracellular diffusion as a form of glucose uptake from the small intestine is subject to much debate. Krehbiel et al. (1996) described passive diffusion as a minor route of glucose absorption in steers with an estimate of $7.4 \%$ of glucose infused into the duodenum being transported this way. However, the infusion study of Krehbiel et al. (1996) involved relatively low luminal glucose concentrations. Kreikemeier et al. (1991) suggest increasing significance of pas- 
sive diffusion as luminal glucose concentration increases. Bauer (1996) suggests that glucose entering by paracellular diffusion may enter the lymphatic drainage and not the portal vein. This could lead to underestimation of the contribution of this transport mechanism to glucose uptake from the intestinal lumen.

Small intestinal fermentation of glucose and starch may be significant in certain dietary situations (Nicoletti et al., 1984). However, little data exists to confirm the importance of this process especially in dairy cows.

Shirazi-Beechey et al. (1995) have shown that the ability of ruminants to adapt to increased duodenal starch supply can be rapid and the capacity to actively transport glucose may increase by a factor of 2 over a two to four day period. However there is less information concerning the nutritional regulation of the sodium independent glucose transport across the basolateral membrane. Research with rats (Cheeseman and Harley, 1991) suggests a proliferation of GLUT2 transporters on high versus low concentrate diets. The simulations of Huntington (1997) indicate that in a steer not adapted to high levcls of postruminal starch delivery, the intestinal glucose transporters may limit glucose uptake in contrast to inadequate enzymic digestion for an adapted steer.

The amount of dietary starch entering the duodenum for cannulated cows in studies from the appendix of Part 1 of the review varied from $0.17 \mathrm{~kg} \mathrm{day}^{-1}$ to $5.8 \mathrm{~kg} \mathrm{day}^{-1}$. Of those cows with ileal cannulae, the mean digestibility of starch entering the small intestine was $67 \%$ with a maximum of $2.4 \mathrm{~kg}^{\text {day }}{ }^{-1}$ being digested in the small intestine. On average, small intestinal digestion accounted for $15 \%$ of total starch digestion with a range of 6 to $42 \%$ depending on the dietary situation.

\section{Starch digestion in the large intestine}

Many researchers have overlooked the digestion of starch in the large intestine and for this reason relatively little quantitative data exists on the products of digestion at this point. Starch escaping degradation by both the microbial activity in the rumen and the enzymatic hydrolysis in the small intestine, may be subject to fermentation in the colon and caecum, along with some hexose sugars escaping complete degradation and absorption. The fermentation is similar to that occurring in the rumen. VFA's from this hind gut fermentation are absorbed but the microbial biomass produced is lost in the faeces. Therefore as relatively more starch is fermented in the large intestine a greater loss of microbial biomass occurs.

Mendoza et al. (1993) demonstrated a 30\% decline in the amount of starch digested in the large intestine of sheep following removal of the protozoa from the rumen. Although Mendoza et al. (1993) offered no explanation for this phenomenon, it is likely that this was simply a result of starch escaping in the defaunated state having a reduced degradation rate due to more complete digestion earlier in the digestive tract. 
Data from the appendix showed that the large intestine contributed up to $26 \%$ of total starch digestion for cows fed dry ground maize (Knowlton et al., 1998). However the mean contribution to total tract starch digestion was only $6 \%$. These data demonstrate the significant role of the large intestinal digestion of starch in certain dietary situations. A need exists for more extensive research of large intestinal digestion in the dairy cow.

\section{Total tract starch digestion}

The previous section has shown that the proportion of starch digested at various sites along the digestive tract can vary considerably. However the data in the appendix of Part 1 of this review also show that total tract starch digestion is less variable and often, almost complete. 19 studies in the appendix show a mean total tract starch digestibility of $93 \%$ ( $\pm 6 \%$ s.d.). This value is marginally lower than other reviews have previously reported (Waldo, 1973; Theurer, 1986; Huntington, 1997). This difference arises from the tendency for studies involving dairy cows to use relatively more ground maize than other more easily degraded starch sources.

Figure 2 of demonstrates that as dietary starch intake increases the total tract digestion of starch increases at an apparently constant rate. The maximum quantity of starch digested per day for these studies was almost $10.3 \mathrm{~kg} \mathrm{day}^{-1}$. This result was obtained for lactating cows fed a diet containing $45 \%$ starch in the DM (McCarthy et al., 1989). The total tract digestibility of starch in this dict was $93.5 \%$, which suggests that the potential for the digestion of large quantities of starch exists without excessive loss of starch in the faeces. Total tract starch digestion was positively correlated with both ruminal and postruminal starch digestion. However, in agreement with Nocek and Tamminga (1991), total tract starch digestion was more closely influenced by ruminal than postruminal digestibility.

\section{The site of starch digestion and its biological significance}

In terms of glucose supply to the dairy cow, intestinal starch digestion and glucose absorption would seem to be more cnergetically efficient than ruminal fermentation of starch to organic acids and subsequent gluconeogenesis from propionate in the liver (Owens et al., 1986). Multiple regression analysis by Owens et al. (1986) demonstrated that for growing cattle small intestinal starch digestion provides $42 \%$ more energy than starch digested in the rumen. However, where large amounts of starch escape rumen fermentation, the capacity for small intestinal digestion of starch and the absorption of the glucose produced in the small intestinal lumen, may be limited in the dairy cow (Owens et al., 1986; Kreikeme- 
年

Total tract starch digestion, g/day

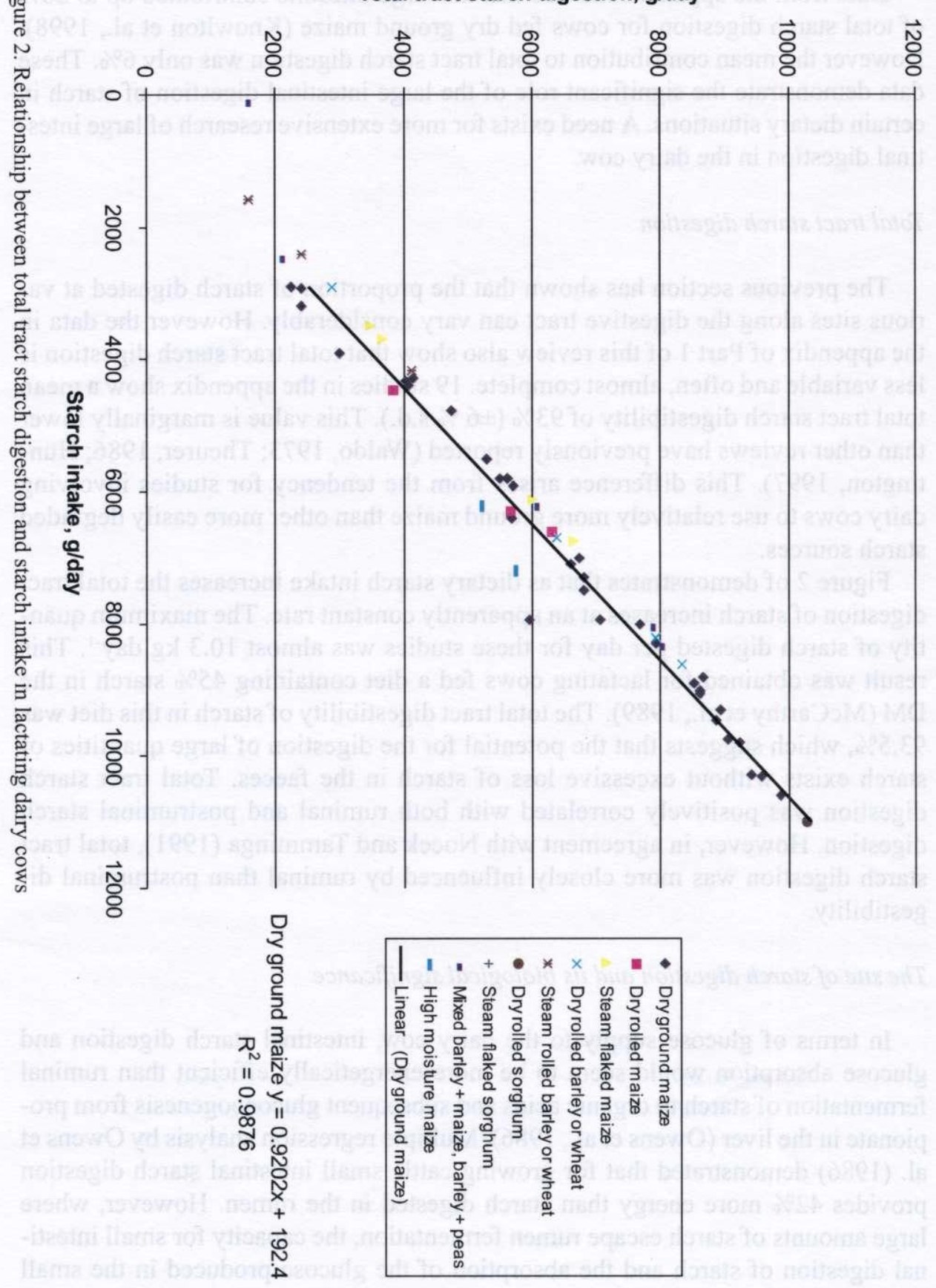


ier and Harmon, 1995). Whilst the relationship depicted by Figure 1 does not suggest an upper limit to postruminal starch digestion, there may be a disproportionate increase in the level of large intestinal starch fermentation as increasing amounts of starch pass undegraded to the duodenum. Available data supporting this concept in dairy cows are extremely limited. However results from Sutton and Oldham as published by Reynolds et al. (1997) show that as starch flow to the duodenum increased by $60 \%$ for a maize based concentrate diet, the relative increases in small intestinal and large intestinal starch digestion were 48 and $99 \%$, respectively. In their review, Owens et al. (1986) also suggested that there was no quantitative limit to small intestinal starch digestion. Nocek and Tamminga (1991) showed that as the amount of starch escaping rumen degradation as a percentage of intake increased, the proportion of this starch that is digested in the small intestine decreased. The data for cows with duodenal and ileal cannulae in the appendix do not show such a clear relationship. The data from Sutton and Oldham involving a 60 and a $90 \%$ maize based concentrate diet show low ruminal degradabilities of 50 and $45 \%$, respectively. However for the same diets the small intestinal digestion of starch entering the duodenum was 74 and $68 \%$, respectively. Indeed, it is often suggested that there is a decline in the digestibility of starch as it passes through the digestive tract due to the removal of the more digestible starch earlier in the digestive tract. For the data in the appendix there was general agreement with this concept except for the data of Sutton and Oldham involving dry ground maize concentrates when small intestinal digestibility exceeded ruminal digestibility by over $20 \%$.

Since total tract starch digestion is positively correlated with ruminal starch digestion, as the proportion of starch digested in the rumen increases the ME supply to the cow also increases and faecal starch loss is reduced. Owens et al. (1986) hypothesised that if starch digested in the small intestine was used $42 \%$ more efficiently than that digested in the rumen, then energetic efficiency would be increased in situations where starch that escapes rumen fermentation was digested to an extent exceeding $70 \%$ of its digestibility in the rumen. However as more starch becomes available for hindgut fermentation, the endogenous faecal nitrogen from microbial biomass produced in the hindgut is increased (Ørskov, 1992), which results in a decrease in apparent nitrogen digestibility. Taniguchi et al. (1995) demonstrated that differences in digestibility between starch infused into the intestine or into the rumen precluded any energetic advantage for intestinally available starch in beef steers. This was before the reduced microbial protein supply was considered.

The synchronisation of energy and protein availability in the rumen for microbial growth has emerged as an important nutritional concept in recent years (AFRC, 1993). Within the rumen, the degradation of feed protein releases ammonia, peptides and amino acids, all of which can be incorporated into microbial protein. The 
microbes require a source of energy for microbial crude protein $(\mathrm{MCP})$ synthesis. Maximising MCP supply, especially where ruminal non-protein nitrogen concentration is high can increase dietary nitrogen retention and increase efficiency. Indeed high levels of ruminal ammonia production can negatively influence digestion and the subsequent elevation in blood urea concentration may cause reproductive failure (Peters and Ball, 1995). It is widely reported in the literature that raising fermentable energy intake using starch leads to increased MCP outflow from the rumen of lactating dairy cattle (Herrera-Saldana and Huber, 1989; Herrera-Saldana et al., 1990; Aldrich et al., 1993). Negative aspects of starch fermentation in the rumen are associated with energy loss from methane production, or the accumulation of fermentation acids predisposing the cow to reduced fibre digestion or even acidosis.

The degradability of the starch clearly affects the extent of its digestion at different sites throughout the digestive tract. The relative proportions of ruminal and post-ruminal starch degradation certainly alter the end products of digestion. This will affect the efficiency of production, although in a review of production studies involving dairy cows, Nocek and Tamminga (1991) concluded that there was no significant evidence to show a quantitative production benefit in altering the site of starch digestion. However dairy cow productivity may be affected in terms of DMI and rumen pH (Knowlton et al., 1998), as a result of manipulating the site of starch digestion. Armstrong et al. (1960) showed that the fate of absorbed energy was different between abomasal and ruminal infusions of glucose with abomasal infusions leading to greater lipid deposition in sheep. Whilst the relative advantages of ruminal or postruminal starch fermentation are closely balanced in terms of energetic efficiency (Taniguchi et al., 1995), the ability of a model to characterise the site of starch digestion is vital, especially with a view to predicting the end products of digestion.

\section{Passage of starch and particle size reduction during digestion}

The influence of both particle size and FSG of digesta on postruminal digestive flow differs from that described in Part 1 of the review regarding flow from the rumen. Siciliano-Jones and Murphy (1986) showed that particle length did not significantly influence postruminal passage. However particles with a FSG between 1.03 and $1.17 \mathrm{~g} / \mathrm{ml}$ tended to pass more quickly than those outside this range. Kaske and Engelhardt (1990) also demonstrated a small but significant $(\mathrm{P}<0.05)$ effect of density on the postruminal passage of plastic particles in sheep with increases in the mean retention time as density increased. Particle length did not influence postruminal passage (Kaske and Engelhardt, 1990). Owens et al. (1986) suggest that the physical size of feed particles containing starch, limits the enzymic degradation of starch in the small intestine. 
Glucose utilisation by the portal-drained viscera and supply to the liver

Whilst this review is concerned with the digestion of starch and its disappearance from the intestinal lumen, it is useful to briefly mention the fate of the absorbed glucose. Following the uptake of glucose from the intestinal lumen by SGLT1, it might be assumed that there would be a net appearance of glucose across the portaldrained viscera (PDV $=$ the gut, pancreas, spleen, mesenteric and omental fat). However the majority of research suggests that there is often no such net absorption due to use of arterial glucose by the PDV in the synthesis of triglyceride or ATP (Huntington, 1982, 1984; Lomax and Baird, 1983; Reynolds et al., 1988). Okine et al. (1994) also suggested that increasing intestinal glucose uptake may spare glutamine from metabolism in the enterocyte. The degree of glucose utilisation by the PDV and hence supply to the liver may depend upon diet characteristics and whether the glucose absorbed from the intestinal lumen is derived from intestinal starch or glucose appearing as a result of an infusion. Bauer (1996) demonstrated increasing PDV glucose use with postruminally supplied starch hydrolysate. This may preclude any energetic advantage of postruminal versus ruminal starch digestion. However, Bauer (1996) suggests that increases in ruminal starch fermentation may also stimulate rumen epithelial metabolism, offsetting any increase in PDV glucose use due to small intestinal digestion. Whether the energetic cost associated with small intestinal starch digestion is disproportionate to that of ruminal starch fermentation is unknown. Even in situations where no net PDV glucose flux is observed, glucose uptake from the small intestine can reduce the requirement for gluconeogenesis in the liver and this may spare amino acids for other metabolic purposes. It is more usual for small intestinal glucose to produce a positive net flux of glucose across the mesenteric drained viscera (MDV) as this excludes blood draining the reticulorumen (Reynolds and Huntington, 1988). Taniguchi et al. (1995) showed that abomasal starch infusions led to a positive PDV glucose flux in beef steers in comparison to similar amounts of starch infused into the rumen. For a full discussion of PDV glucose flux and the factors influencing the utilisation of adsorbed glucose by the PDV the reader is referred to Reynolds et al. (1997).

\section{FACTORS INFLUENCING THE NATURE OF STARCH DIGESTION IN THE POSTRUMINAL DIGESTIVE TRACT OF THE LACTATING DAIRY COW}

\section{Starch source}

Variety. The influence of cereal grain variety on postruminal digestibility is less well established than its effect on rumen degradation. However, Streeter et al. (1990) used cannulated steers to demonstrate that although the starch digestibility 
within the rumen did not differ, starch entering the small intestine showed digestibilities as a percentage of starch entering the intestine ranging from $12 \%$ for yellow sorghum to $29 \%$ for hetero-yellow sorghum grain. However, total tract digestibility was similar for all varieties due to increased large intestinal digestibility of starch from yellow sorghum grain.

Feedstuffs. Postruminal digestion as a percentage of total digestion tends to be less for wheat and barley than for maize and sorghum starches (Part 1 of review, Table 8). Postruminal digestion accounted for $33 \%$ of total starch digestion for dry rolled maize and for $44 \%$ with dry rolled sorghum, in comparison to just $14 \%$ for dry rolled barley. Due to the compensatory effect of postruminal digestion, total tract starch digestion is often only marginally different between different starch types. Table 2 shows data from Sutton and Oldham and published by Reynolds et al. (1997) involving 4 dairy cows equipped with duodenal and ileal cannulae. This study compared two inclusion levels of a maize or barley based concentrate.

TABLE 2

Starch digestion throughout the gastrointestinal lact of 4 lactating dairy cows

\begin{tabular}{lcccc}
\hline & Barley $60 \%$ & Barley $90 \%$ & Maize $60 \%$ & Maize 90\% \\
\hline DMI, kg/day & 12.9 & 11.0 & 12.4 & 12.0 \\
Milk yield, kg/day & 14.6 & 14.5 & 15.6 & 17.5 \\
& & & & \\
Starch passage, kg/day & & & 4.4 & 6.4 \\
$\quad$ intake & 4.0 & 5.5 & 2.2 & 3.5 \\
$\quad$ duodenal & 0.6 & 0.8 & 0.6 & 1.1 \\
$\quad$ ileal & 0.1 & 0.2 & 0.2 & 0.7 \\
$\quad$ faecal & 0.1 & 0.1 & & \\
Starch digestion, g/kg/entering & & & 507 & 454 \\
$\quad$ rumen & 843 & 857 & 738 & 676 \\
$\quad$ small intestine & 773 & 715 & 438 & 368 \\
$\quad$ hindgut & 562 & 663 & & \\
\hline
\end{tabular}

Sutton and Oldham as published by Reynolds et al. (1997)

data presented are means unadjusted for missing observations or period effects due to experimental design

The digestibility of the maize starch remained lower throughout the digestive tract, although differences in small intestinal digestibility were only $5 \%$ for both inclusion levels. Therefore due to large differences in postruminal starch delivery, the total quantity of starch digested in the small intestine, was much greater for maize ( 1.6 and $\left.2.4 \mathrm{~kg} \mathrm{day}^{-1}\right)$ than for barley $\left(0.5\right.$ and $\left.0.6 \mathrm{~kg} \mathrm{day}^{-1}\right)$. 


\section{Feedstuff processing}

Table 8 in Part 1 of the review shows mean digestibility coefficients for different starch sources following various processing methods. Both dry rolled maize and sorghum displayed low mean postruminal digestibilities relative to steam treatment. In contrast, dry ground maize displayed a relatively high postruminal digestibility of $89 \%$ as a percentage of duodenal starch flow. This resulted in $50 \%$ of total tract starch digestion for dry ground maize occurring postruminally. These data agree with the review of Huntington (1997) using data based primarily on non-lactating cattle. Knowlton et al. (1998) showed that high moisture treatment of maize decreased large intestinal starch digestion and increased the proportion of starch digestion in the small intestine as a percentage of total tract digestion. Knowlton et al. (1998) also showed that total tract digestion of starch increased from $83 \%$ for dry rolled maize to $97 \%$ for high moisture ensiled maize. Ensiling exposes the maize grain to heat, moisture and pressure, which causes the starch granules to be exposed at the same time as inducing gelatinisation.

When cereal grains are steam flaked, the density of the flaked grain influences the susceptibility to enzymatic degradation and hence the site of digestion. When steam flaked maize was fed to steers the flake density was inversely related to both in vitro and in vivo starch digestibility (Zinn, 1990) (Part 1 of review, Figure 7). Zinn (1990) states that the ability of different flake densities to influence postruminal starch digestibility shows how the physical characteristics of feed particles can limit intestinal starch digestion.

\section{Dietary protein and non-protein nitrogen concentrations}

Klusmeyer et al. (1990) did not observe any increase in apparent ruminal or post-ruminal starch digestibility as dietary crude protein concentration increased from 11 to $14.5 \%$. Duodenal infusion of the amino acids lysine and methionine increased total tract starch digestibility due to increases in postruminal starch digestibility (Lynch et al., 1991). Adding $8 \%$ animal protein to the diets of dairy cows increased the digestibility of starch in the small intestine by $5 \%$ and decreased the digestibility of starch in the large intestine by $17 \%$ (Palmquist et al., 1993). In the same study intestinal starch digestibility as a whole was increased with protein supplementation. However the results are confounded by the large variation in starch intakes between the different treatments. Klusmeyer et al. (1991) showed no difference in the digestion of starch for lactating cows fed either soyabean meal or fish meal as the dietary protein source. Taniguchi et al. $(1993,1995)$ described how the abomasal infusion of casein with maize starch led to elevated intestinal starch digestion in comparison to infusions of maize starch alone and this is highlighted in Table 3. Castlebury and Preston (1993) 
used lambs to demonstrate increased postruminal starch digestion with increasing dietary protein level. This has implications for situations where increased levels of ruminally degraded dietary starch lead to an elevated microbial protein flow to the duodenum.

Johnson et al. (1977) showed an increase in pancreatic $\alpha$-amylase synthesis in rats as a direct result of casein inclusion in the diet. These data support the theory relating to the stimulation of pancreatic exocrine secretion with increased duodenal protein supply as presented by Fushiki and Iwai (1989). Therefore it is reasonable to assume that such digestive responses as seen by Taniguchi et al. (1995, 1993) and Palmquist et al. (1993) are the result of the effect of intestinal protein supply on pancreatic secretion. The low starch digestibility observed for the zero level of casein infusion in Table 3 could also be due to inadequate oligosaccharidase synthesis on this protein free diet (Taniguchi et al., 1993). Large intestinal digestion of starch tends to be less influenced by dietary protein intake.

TABLE 3

Effect of abomasal casein infusions on intestinal digestibility of maize starch in sheep

\begin{tabular}{lcr}
\hline \multirow{2}{*}{ Digestion site } & \multicolumn{2}{c}{ Casein level, g/d } \\
\cline { 2 - 3 } & 0 & \multicolumn{1}{c}{120} \\
\hline Small intestinal digestibility, \% a & $54.9 \pm 14.8^{1}$ & $92.5 \pm 3.4$ \\
Large intestinal digestibility, \% ${ }^{\text {b }}$ & $43.0 \pm 15.2$ & $6.2 \pm 3.0$ \\
Total & $97.9 \pm 1.4$ & $98.6 \pm 1.0$ \\
\hline
\end{tabular}

${ }^{1}$ mean \pm standard deviation $(n=4)$

${ }^{a}$ means are significantly different $(\mathrm{P}<0.05)$

${ }^{\mathrm{b}}$ means are significantly different $(\mathrm{P}<0.01)$

Taniguchi et al., 1993

\section{Dietary fat}

Palmquist et al. (1993) demonstrated a 10\% decline in small intestinal starch digestibility with the inclusion of added fat. When Klusmeyer et al. (1991) fed lactating cows calcium salts of long chain fatty acids (Ca LCFA), a ruminally inert form of fat, at $4 \%$ of dietary DM, cows tended to digest a smaller percentage ( 40.8 vs $47.3 \%$ ) of starch in the rumen. However, both the subsequent digestibility of the starch passing to the duodenum and total tract starch digestibility were raised where Ca LCFA was fed. Klusmeyer et al. (1991) suggested that the reduced feed intake observed where cows were fed Ca LCFA could have caused such results. 


\section{Antinutritional factors}

Data from ruminants shows that post ruminal digestion of starch is not affected by the inclusion of phenolics in the diet (Mahmoudzadeh et al., 1989), possibly due to inactivation in the abomasum.

\section{Animal factors}

Booher et al. (1951) showed that the apparent digestibility of uncooked potato starch increased following prolonged feeding to young rats. Dietary changes can also affect starch digestion in the small intestine as shown by short term infusion studies (Kreikemeier et al., 1991; Kreikemeier and Harmon, 1991). Kreikemeier et al. (1991) demonstrated that as starch supply to the abomasum increased, the proportion digested in the small intestine decreased. However where both growing and dairy cattle are adapted to their diets a positive relationship exists between the rate of starch digestion and starch delivery in the small intestine (Owens et al., 1986; Nocek and Tamminga, 1991; Reynolds et al., 1997).

Pehrson and Knutson (1980) examined small intestinal glucose absorption in dairy cows at different stages of lactation. Abomasal infusions of glucose were absorbed to a similar extent in both a high yielding cow at early lactation and a low yielding cow at late lactation. Demand for glucose by the mammary gland did not influence intestinal glucose absorption. When a high yiclding cow was compulsorily dried off, glucose absorption was unaltered but plasma glucose concentrations increased. Okine et al. (1994) used duodenal tissue sheets taken from dairy cows at different stages of lactation in order to examine both glucose and amino acid transport. The mean affinity constant $\left(\mathrm{K}_{\mathrm{m}}\right)$ of glucose for its transport system tended to increase for late lactation cows relative to early lactation cows (Table 1) although the results were not statistically significant. However the capacity of the duodenal sheets to transport glucose was more than double in lactating cows than non-lactating cows. Early lactation cows metabolised a greater percentage of absorbed glucose carbon to carbon dioxide than mid, late or nonlactating cows.

\section{TOWARDS A DYNAMIC MECHANISTIC MODEL OF STARCH DIGESTION IN THE LACTATING DAIRY COW - KEY PRINCIPLES}

Several models of ruminant digestion have been proposed in the literature. Much of the emphasis in these models is placed on digestion within the rumen (Baldwin et al., 1977, 1987; France et al., 1982; Dijkstra et al., 1992; Baldwin, 1995). When examining digestion purely in terms of that which takes place in 
the rumen, nutrient availability to the cow can not necessarily be accurately predicted. As this review has shown, the compensatory effect of increased postruminal digestion can prevent depressions in rumen digestibility being transferred to reductions in total tract digestibility. Therefore one initial condition of a starch digestion model is that it represents the entire digestive tract. Duc to the differing objectives behind the various models described in the literature and the continual improvement in biological knowledge, starch digestion is represented in varying degrees of detail along with the digestion of other dietary carbohydrates. The purpose of this section is not to examine the specific mathematical description of these models, but to summarise the different approaches used to represent starch digestion in the dairy cow. Hence relevant schematic descriptions of starch digestion that are presented in the literature but not part of working models are also included in the following discussion.

\section{Dietary starch}

Early mechanistic models of rumen digestion avoided description of feeds in terms of their physical attributes (Baldwin et al., 1977; Black et al., 1981; France et al., 1982). A more recent trend has been to describe the ingested nutrients in terms of their particle size distribution (Baldwin et al., 1987; Murphy and Kennedy, 1993; Baldwin, 1995). This accounts for differential degradation and passage rates of small and large particles, as well as soluble nutrients. This review has shown how processing can dramatically influence degradation rates of starch not only in the rumen but also throughout the entire digestive tract. This is in part due to particle size characteristics. Therefore adequate representation of the distribution of starch between different particle sizes should facilitate a more accurate description of feedstuffs that have been processed differently.

\section{Postruminal digestion}

More attention has been given to representing postruminal starch digestion in diagrammatic form than that seen in most working models of ruminant digestion. Contrary to their rumen model, Nocek and Tamminga (1991) describe the inputs to the small intestine in terms of large, medium and small particle sizes. These compartments are continucd through to the large intestine and the output in the facces. However, no account is taken of the contribution of hindgut starch digestion towards the production of microbial biomass. Representation of large intestinal digestion of starch is often inadequate or even ignored in models of digestion, in part due to the lack of quantitative research data. Where postruminal starch digestion is represented in the modelling process, it is usually empirical in nature. Baldwin et al. (1987) assumed a constant digestion coefficient 
for this part of the digestive process and completely ignored large intestinal fermentation. Since postruminal starch digestion in the dairy cow can account for up to $50 \%$ of total tract starch digestion (see Part 1 of review, Table 8), its accurate description during the modelling procedure deserves more attention than it has previously been afforded.

Ewing and Johnson (1987) used the in vitro digestion rates reported for ground maize by Tonroy and Perry (1974) to describe the digestion of starch in the small intestine. The digestion rate coefficient was then adjusted for different particle sizes based upon the increase in surface area as particle size declined. Particle size reduction resulting from the enzymatic action was also accounted for in their model. However, whole intact maize grains were deemed to pass undigested into the faeces.

Huntington (1997) simulated the small intestinal digestion of starch and uptake of glucose for a lactating dairy cow using a model based around the division of the small intestine into $1 \mathrm{~m}$ sections and performing calculations of digestion and absorption at each section. SGLT1 transporter activity was distributed according to data from mouse and rat intestine (Ferraris et al., 1989). Dividing the small intestine into sections would seem to be a sensible approach to the simulation process. Parameters other than just SGLT1 transporter presence could be varied between the regions. This approach highlights the importance of intestinal length as a variable that will influence both digestive and absorptive capacities, but also indicates the need to define quantitatively the factors that influence the length of the intestine.

This review has shown that the following elements can significantly influence small intestinal starch digestion and should therefore be represented in a forthcoming model.

1. Enzyme secretion / activity / distribution pancreatic $\alpha$-amylase intestinal oligosaccharidase

2. Particle size of digesta entering the duodenum

3. Absorptive capacity

active and passive transport at different sections of intestine.

Pancreatic $\alpha$-amylase secretion could be a function of energy intake, duodenal starch flow, and duodenal protein supply. Adequate division of digesta into different particle size pools allows the effect of surface area/starch ratio to be taken into account during enzymatic degradation. Small intestinal glucose uptake will itself influence flow to the large intestine as well as plasma glucose concentration. The effect of both luminal and plasma glucose concentration upon enzyme secretion can also be described. 


\section{Model evaluation}

As stated in Part 1 of the review, Ewing and Johnson (1987) found initial simulations of their model to be unacceptable with regard to predicted starch digestibilities through the digestive tract. Digestion rates were subsequently altered to allow prediction of data from Turgeon et al. (1983). In vitro and in situ data used to build the model and predict in vivo starch digestion rates were considered inadequate, as with the rumen elements of the model. Subsequent to parameter re-estimation the relationship between predicted and observed values of total tract digestion was poor $(\mathrm{R}=0.237)$.

The simulations of Huntington (1997) show potential as an approach that could be used to predict intestinal glucose absorption. However, when the simulation involved dairy cows the predictions were not evaluated against experimental observations. Huntington (1997) was forced to set the affinity constant $\left(\mathrm{k}_{\mathrm{m}}\right)$ of the SGLT1 for glucose at $5 \mathrm{mM}$ luminal glucose concentration. This is only marginally below the apparent in vivo reported values for bovine SGLT I (see Table 1). The predictions of the relative contributions of active glucose uptake from the intestinal lumen and paracellular diffusion of glucose were in line with reported values of Pappenheimer and Reiss (1987) for an investigation involving rats.

A CONCEPTUAL FRAMEWORK FOR A MECHANISTIC MODEL OF POSTRUMINAL STARCH DIGESTION AND GLUCOSE ABSORPTION IN THE LACTATING DAIRY COW

\section{Objective}

Figures 3 and 4 show the biological basis for a mechanistic model of starch digestion in the small intestine and large intestine, respectively. The objective of this model is to define the end products of digestion as they occur for different quantities and sources of rumen escape starch and to predict their absorption from the digestive tract. The model considers the disappearance of starch from the intestinal lumen as a result of the competition between starch digestion followed by glucose absorption and passage along the digestive tract. As stated in Part 1 of the review, it is important to consider such a model as an element within a scheme representing the digestion of other major dietary components such as protein and fibre. However, unlike the rumen, such description of other dietary components cannot be drawn from existing mechanistic models due to their lack of description in this area. 


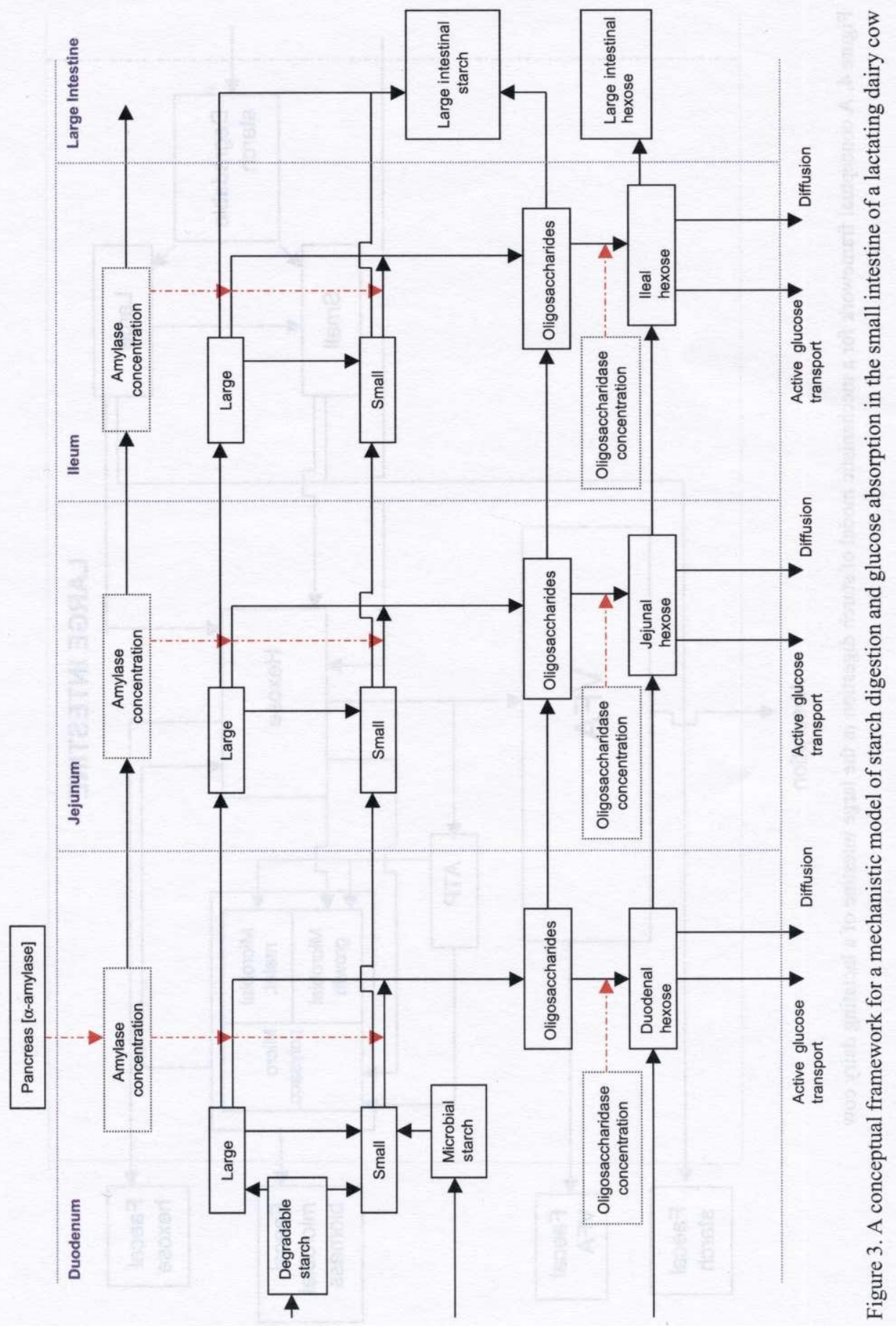




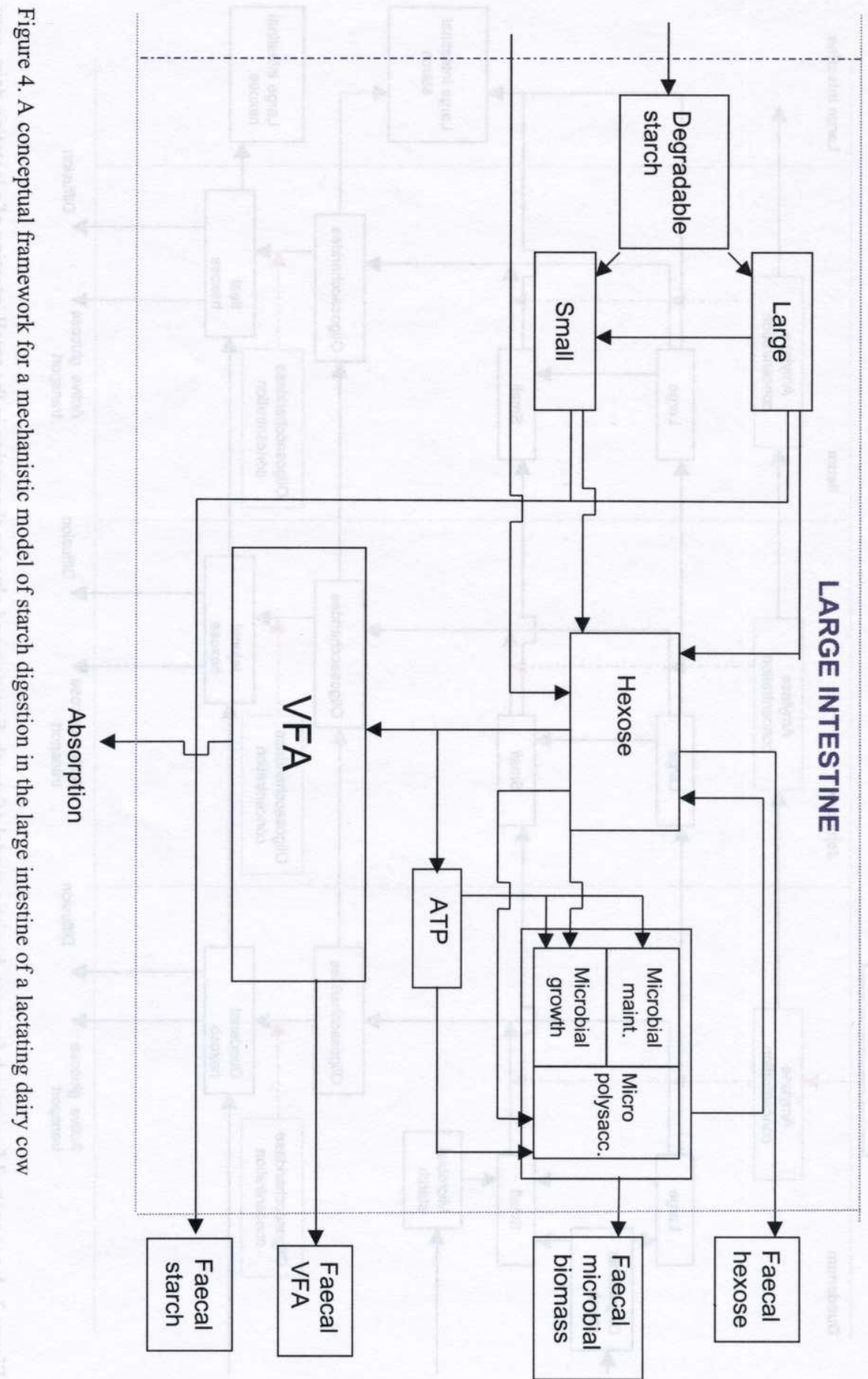




\section{Postruminal description}

Starch arriving at the small intestine is derived mainly dietary starch that remains undegraded within the rumen. Microbial starch, the composition of which will depend upon the microbial starch content and relative outflow rates of bacteria and protozoa, is also represented. For the purpose of the model, the microbial starch is considered to enter the small particle pool. A pathway exists, albeit of limited significance, for the passage of bexose directly from the rumen to join the small intestinal hexose pool. The small intestinal model is the product of three separate sections: the duodenum, jejunum and ileum. The framework for each of the three sections is similar in structure with the facility to change parameter values such as those relating to enzyme activity and SGLT1 density. Pancreatic secretion occurs only in the duodenal section and it depends on duodenal protein and starch flows as well as ME intake. The flow of starch from the duodenum forms the input to the jejunum and outputs from the jejunum represent inputs to the ileum. Pancreatic $\alpha$-amylase concentration in the duodenum depends upon pancreatic secretion and rate of outflow to the jejunum. Therefore concentration of pancreatic $\alpha$-amylase in the jejunum and ileum is dependent upon prior secretion and digesta flow. A function representing the degradation of $\alpha$-amylase over time is also needed due to the proteolytic activity of other intestinal secretions. The length of the small intestine may be a function of body size and ME intake. It is the length of each intestinal region in combination with the concentration of enzymes and SGLT1 transporters that determines the digestive and absorptive capacities, respectively. Oligosaccharidase concentration per unit length of intestine is considered fixed within each region of the small intestine although it varies between regions. Dietary influences on the concentration of oligosaccharidase are assumed to be insignificant. However, diet may influence the length of the small intestine, which in turn determines the total oligosaccharidase activity. Since oligosaccharidase concentration is fixed, any breakdown of these enzymes is ignored, with synthesis equal to degradation. The size of the hexose pool will also be affected by the rate of glucose uptake as well as starch degradation. Glucose uptake is a function of both passive diffusion and active transport. Representation of paracellular diffusion necessitates the provision of blood glucose concentration as a driving variable to the model.

The digestion of starch in the large intestine is similar to that for the rumen. However outputs from the system, other than VFA, are unavailable to the cow as a supply of nutrients and are lost in the faecal output. The distinction of protozoa within the microbial pool is not made in order to simplify the system. Protein and non-protein nitrogen supply to the large intestine is not easy to accurately quantify without another model relating to the digestion of protein and uptake of amino acids within the small intestine. However most of the studies involving cows with 
ileal cannulae show an excess of protein arriving at the large intestine with normal diets. Therefore the model could assume that protein does not limit starch digestion at this stage.

When examined in terms of the organisational hierarchy as proposed by France and Thomley (1984) the structure of the model is one that involves a reductionist approach. Starch, a macromolecule, represents level $i$ with hexose representing level $i-1$. This framework would seem to provide a level of complexity that is manageable whilst allowing a true representation of the biology relating to starch digestion in the dairy cow. Estimates for the majority of the required parameters are available in the literature. Following appropriate mathematical expression and combination with a model of events in the rumen (see Part 1 of the review), the model should provide a system that can accommodate contrasting dietary scenarios. Whether the dietary starch source consists of whole wheat grains, dry ground sorghum or steam flaked barley, this framework should have the ability to predict the products of digestion that are subsequently so influential on lactational performance by the dairy cow.

\section{REFERENCES}

AFRC, 1993. Energy and Protein Requirements of Ruminants. CAB International, Wallingford AFRC, 1999. Response in the yield of milk constituents to the intake of nutrients by dairy cows, Report No. 11. CAB International, Wallingford

Aldrich J.M., Muller L.D., Varga G.A., Griel L.C., 1993. Nonstructural carbohydrate and protein effects on rumen fermentation, nutrient flow, and performance of dairy cows. J. Dairy Sci. 76, $1091-1105$

Armstrong D.G., Blaxter K.L., McC. Graham N., 1960. Fat synthesis from glucose by sheep. Proc. Nutr. Soc. 19, XXXI-XXXII

Baldwin R.L., 1995. Modeling Ruminant Digestion and Metabolism. Chapman and Hall, London

Baldwin R.L., Koong L.J., Ulyatt M.J., 1977. A dynamic model of ruminant digestion for evaluation of factors affecting nutritive value. Agr. Syst. 2, 255-288

Baldwin R.L., Thornley J.H.M., Beever D.E., 1987. Metabolism of the lactating cow Il. Digestive elements of a mechanistic model. J. Dairy Res. 54, 107-131

Barry P.H., Diamond J.M., 1984. Effects of unstirred layers on membrane phenomena. Physiol. Rev. $64,763-872$

Bauer M.L., 1996. Nutritional regulation of small intestinal glucose absorption in ruminants. Ph.D. Dissertation. University of Kentucky, Lexington

Bauer M.L., Harmon D.L., Bohnert D.W., Branco A.F., Huntington G.B., 1997. Influence of $\alpha$-linked glucose on sodium-glucose cotransport activity along the small intestine in cattle. J. Anim. Sci. 75, Suppl 1, 263 (Abstr.)

Beever D.E., Rook A.J., France J., Dhanoa M.S., Gill M., 1991. A review of empirical and mechanistic models of lactational performance by the dairy cow. Livest. Prod. Sci. 29, 115-130

Black J.L., Beever D.E., Faichney G.J., Howarth B.R., Graham N.M., 1981. Simulation of the effects of rumen function on the flow of nutrients from the stomach of sheep: part 1-description of a computer program. Agr. Syst. 6, 195-219 
Booher L.E., Behan I., McMeans E., 1951. Biologic utilization of unmodified and modified food starches. J. Nutr. 45, 75-95

Call J.L., Mitchell G.E., Little C.O., 1975. Response of ovine pancreatic amylase to elevated blood glucose. J. Anim. Sci. 41, 1717-1721

Castlebury R.E., Preston R.L., 1993. Effect of dietary protein level on nutrient digestion in lambs duodenally infused with corn starch. J. Anim. Sci. 71, Suppl. 1, 264 (Abstr. 692)

Cheeseman C.I., Harley B., 1991. Adaptation of glucose transport across rat enterocyte basolateral membrane in response to altered dietary carbohydrate intake. J. Physiol. 437, 563-575

Chittenden L.W., Johnson D.D., Mitchell G.E., Tucker R.E., 1984. Ovine pancreatic amylase response to form of carbohydrate. Nutr. Rep. Int. 29, $1051-1060$

Cone J.W., 1991. Degradation of starch in feed concentrates by enzymes, rumen fluid and rumen enzymes. J. Sci. Food Agr. 54, 23-34

Cone J.W., Cliné-Theil W., Malestein A., van't Klooster A.T., 1989. Degradation of starch by incubation with rumen fluid. A comparison of different starch sources. J. Sci. Food Agr. 49, 173-183

Coombe N.B., Siddons R.C., 1973. Carbohydrases of the bovine small intestine. Brit. J. Nutr. 30, 269-276

Czerkawski J.W., 1978. Reassessment of efficiency of synthesis of microbial matter in the rumen. J. Dairy Sci. 61, 1261-1273

Dijkstra J., Neal H.D.St.C., Beever D.E., France J., 1992. Simulation of nutrient digestion, absorption and outflow in the rumen: model description. J. Nutr. 122, 2239-2256

Ewing D.L., Johnson D.E., 1987. Corn particle starch digestion, passage and size reduction in beef steers: a dynamic model. J. Anim. Sci. 64, 1194-1204

Faichney G.J., 1989. Mean retention time and intra-ruminal degradation of rumen protozoa. Proc. Nutr. Soc.-Aust. 14, 135

Ferraris R.P., Lee P.P., Diamond J.M., 1989. Origin of regional and species differences in intestinal glucose uptake. Amer. J. Physiol. 257, G689-G697

Ferraris R.P., Yasharpour S., Kent Lloyd K.C., Mirzayan R., Diamond J.M., 1990. Luminal glucose concentrations in the gut under normal conditions. Amer. J. Physiol. 259, G822-G837

France J., Thornley J.H.M., 1984. Mathematical Models in Agriculture. Butterworths, London

France J., Thornley J.H.M., Beever D.E., 1982. A mathematical model of the rumen. J. Agr. Sci. 99. 343-353

Fushiki T., Iwai K., 1989. Two hypotheses on the feedback regulation of pancreatic enzyme secretion. Fed. Amer. Soc. Exp. Biol. J. 3, 121-126

Gill M., France J., Summers M., McBride B.W., Milligan L.P., 1989. Simulation of the energy costs associated with protein turnover and $\mathrm{Na}^{+}, \mathrm{K}^{+}$-transport in growing lambs. J. Nutr. 119 , $1287-1299$

Gray G.M., 1992. Starch digestion and absorption in nonruminants. J. Nutr. 122, 172-177

Harmon D.L., 1992. Dietary influences on carbohydrases and small intestinal starch hydolysis capacity in ruminants. J. Nutr. 122, 203-210

Harmon D.L., 1993. Nutritional regulation of postruminal digestive enzymes in ruminants. J. Dairy Sci. 76, 2102-2111

Herrera-Saldana R.E., Gomez-Alarcon R., Torabi M., Huber J.T., 1990. Influence of synchronizing protein and starch degradation in the rumen on nutrient utilization and microbial protein synthesis. J. Dairy Sci. 73, 142-148

Herrera-Saldana R.E., Huber J.T., 1989. Influence of varying protein and starch degradabilities on performance of lactating cows. J. Dairy Sci. 72, 1477-1483

Huntington G.B., 1982. Portal blood flow and net absorption of ammonia-nitrogen, urea-nitrogen, and glucose in nonlactating Holstein cows. J. Dairy Sci. 65, 1155-1162 
Huntington G.B., 1984. Net absorption of glucose and nitrogenous compounds by lactating Holstein cows. J. Dairy Sci. 67, 1919-1927

Huntington G.B., 1997. Starch utilization by ruminants: From basics to the bunk. J. Anim. Sci. 75, 852-867

Janes A.N., Weekes T.E.C., Armstrong D.G., 1985. Carbohydrase activity in the pancreatic tissue and small intestine mucosa of sheep fed dried grass or maize based diets. J. Agr. Sci. 104, 435-443

Johnson D.D., Hurwitz A.R., Kretchmer N., 1977. Adaptation of rat pancreatic amylase and chymotrysinogen to changes in diet. J. Nutr. 107, 87-96

Johnson D.D., Mitchell G.E., Tucker,R.E., Muntifering R.B., 1986. Pancreatic amylase, plasma glucose, and insulin responses to propionate or monensin in sheep. J. Dairy Sci. 69, 52-57

Jones B.J., Brown B.E., Loran J.S., Edgerton D., Kennedy J.F., Stead J.A., Silk, D.B., 1983. Glucose absorption from starch hydrolysates in the human jejunum. Gut $24,1152-1160$

Kaske M., Engelhardt W.V., 1990. The effect of size and density on mean retention time of particles in the gastrointestinal tract of sheep. Brit. J. Nutr. 63, 457-465

Kato S., Ando T., Adachi N., Minco H., 1989. Effect of short-chain fally acids on pancreatic exocrine secretion in calves aged 2 weeks and 13 weeks. Jpn. J. Vet. Sci. 51,1123

Klusmeyer T.H., Lynch G.L., Clark J.H., Nelson D.R., 1991. Effects of calcium salts of fatty acids and protein source on ruminal fermentation and nutrient flow to duodenum of cows. J. Dairy Sci. 74, 2206-2219

Klusmeyer T.H., McCarthy R.D., Clark J.H., Nelson D.R., 1990. Effects of source and amount of protein on ruminal fermentation and passage of nutrients to the small intestine of lactating cows. J. Dairy Sci. 73, 3526-3537

Knowlton K.F., Glenn B.P., Erdman R.A., 1998. Performance, ruminal fermentation, and site of starch digestion in early lactation cows fed corn grain harvested and processed differently. J. Dairy Sci. 81, 1972-1984

Krehbiel C.R., Britton R.A., Harmon D.L., Peters J.P., Stock R.A., Grotjan H.E., 1996. Effects of varying levels of duodenal or midjejunal glucose and 2-deoxyglucose infusion on small intestinal disappearance and net portal glucose flux in steers. J. Anim. Sci. 74, 693-700

Kreikemeicr K.K., Harmon D.L., 1991. Effect of abomasal carbohydrate infusion on ileal digesta oligosaccharide flow in steers. J. Anim. Sci. 69, 517 (Abstr.)

Kreikemeier K.K., Harmon D.L., 1995. Abomasal glucose, maize starch and maize dextrin infusions in cattle: Small intestinal disappearance, net portal glucose flux and ileal oligosaccharide flow. Brit. J. Nutr. 73, 763-772

Kreikemeier K.K., Harmon D.L., Brandt R.T., Avery T.B., Johnson D.E., 1991. Small intestinal starch digestion in steers: Effect of various levels of abomasal glusose, corn starch and corn dextrin on small intestinal disappearance and net glucose absorption. J. Anim. Sci. 69, 328-338

Kreikemeier K.K., Harmon D.L., Peters J.P., Gross K.L., Armendariz C.K., Krehbiel C.R., 1990. Influence of dietary forage and feed intake on carbohydrase activities and small intestinal morphology of calves. J. Anim. Sci. 68, 2916-2929

Lomax M.A., Baird G.D., 1983. Blood flow and nutrient exchange across the liver and gut of the dairy cow. Effects of lactation and fasting. Brit. J. Nutr. 49, 481-496

Lynch G.L., Klusmeyer, T.H. Cameron M.R., Clark J.H.,.Nelson D.R., 1991. Effects of somatotrophin and duodenal infusion of amino acids on nutrient passage to duodenum and performance of dairy cows. J. Dairy Sci. 74, 3117-3127

Maenz D.D., Cheeseman C.I., 1987. The $\mathrm{Na}^{+}$-independent D-glucose transporter in the enterocyte basolateral membrane. J. Membrane Biol. 97, 259-266

Mahmoudzadeh H., Karangwa E., Mitchell G.E., Muntifering R.B., Tucker R.E., 1989. Post-ruminal digestion of starch in the presence of phenolic monomers. Anim. Feed Sci. Tech. 27, 111-116 
McCarthy R.D., Klusmeyer T.H., Vicini J.L., Clark J.H., Nelson D.R., 1989. Effects of source of protein and carbohydrate on ruminal fermentation and passage of nutrients to the small intestine of lactating cows. J. Dairy Sci. 72, 2002-2016

Meddings J.B., Westergaard H., 1989. Intestinal glucose transport using in vivo perfused rat jejunum: model analysis and derivation of corrected kinetic constants. Clin. Sci. Lond. 76, 403-413

Mendoza G.D., Britton R.A., Stock R.A., 1993. Influence of ruminal protozoa on site and extent of starch digestion and ruminal fermentation. J. Anim. Sci. 71, 1572-1578

Murphy M.R., Kennedy P.M., 1993. Particle dynamics. In: J.M. Forbes. J. France (Editors). Quantitative Aspects of Ruminant Digestion and Metabolism. CAB International, Wallingford, pp. 87-105

Nicoletti J.M., Davis C.L., Hespell R.B., Leedle J.A.Z., 1984. Enumeration and presumptive identification of bacteria from the small intestine of sheep. J. Dairy Sci. 67, 1227-1235

Nocek J.E., Tamminga S., 1991. Site of digestion of starch in the gastrointestinal tract of dairy cows and its effect on milk yield and composition. J. Dairy Sci. 74, 3598-3629

Okine E.K., Cherry R., Kennelly J.J., 1994. Glucose and amino acid transport and metabolism in flat duodenal sheets of dairy cattle at three stages of lactation. Comp. Biochem. Physiol. 107A, 719-726

Owens F.N., Zinn R.A., Kim Y.K., 1986. Limits to starch digestion in the ruminant small intestine. J. Anim. Sci. 63, 1634-1648

Ørskov E.R., 1992. Protein Nutrition in Ruminants. 2nd Edition. Academic Press Ltd., London

Palmquist D.L., Weisbjerg M.R., Hvelplund T., 1993. Ruminal, intestinal, and total tract digestibilities of nutrients in cows fed diets high in fat and undegradable protein. J. Dairy Sci. 76, 1353-1364

Pappenheimer J.R., Reiss K.Z., 1987. Contribution of solvent drag through intercellular junctions to absorption of nutrients by the small intestine of the rat. J. Membrane Biol. 100, 123-136

Pehrson B., Knutson M., 1980. Glucose and lactose absorption from the small intestine of dairy cows. Zbl. Vet. Med. A 27, 644-651

Peters A.R., Ball P.J.H., 1995. Reproduction in Cattle. 2nd Edition. Blackwell Science, Oxford

Reynolds C.K., Huntington G.B., 1988. Partition of portal-drained visceral net flux in beef steers. 2 . Net flux of volatile fatty acids, D- $\beta$-hydroxybutyrate and L-lactate across stomach and poststomach tissues. Brit. J. Nutr. 60, 553-562

Reynolds C.K., Huntington G.B., Reynolds P.J., 1988. Net portal-drained visceral and hepatic metabolism of glucose, L-lactate and nitrogenous compounds in lactating Holstein cows. J. Dairy Sci. $71,1803-1812$

Reynolds C.K., Sutton J.D., Beever D.E., 1997. Effects of feeding starch to dairy cattle on nutrient availability and production. In: P.C. Garnsworthy, J. Wiseman, W. Haresign (Editors). Recent Advances in Animal Nutrition. Nottingham University Press, Nottingham, pp. 105-133

Russell J.R., Young A.W., Jorgensen N.A., 1981. Effect of dietary corn starch intake on ruminal small intestinal and large intestinal starch digestion in cattle. J. Anim. Sci. 52, 1170-1176

Shirazi-Beechey S.P., Wood I.S., Dyer J., Scott D., King T.P., 1995. Intestinal sugar transport in ruminants. In: W.V. Engelhardt, S. Leonhard-Marek, G. Breves, D. Giesecke (Editors). Ruminant Physiology: Digestion, Metabolism, Growth and Reproduction. Proceedings of the 8th International Symposium on Ruminant Physiology. Ferdinand Enke Verlag, Stuttgart, pp. 117-133

Siciliano-Jones J., Murphy M.R., 1986. Passage of inert particles varying in lengthand specific gravity through the postruminal digestive tract of steers. J. Dairy Sci. 69, 2304-2311

Streeter M.N., Wagner D.G., Hibberd C.A., Owens F.N., 1990. Comparison of corn with four sorghum grain hybrids: site and extent of digestion in steers. J. Anim. Sci. 68, 3429-3440

Taniguchi K., Huntington G.B., Glenn B.P., 1995. Net nutrient flux by visceral tissues of beef steers given abomasal and ruminal infusions of casein and starch. J. Anim. Sci. 73, 236-249 
Taniguchi K., Sunada Y., Obitsu T., 1993. Starch digestion in the small intestine of sheep sustained by intragastric infusion without protein supply. Anim. Sci. Tech. (Jpn) 64, 892-895

Theurer C.B., 1986. Grain processing effects on starch utilization by ruminants. J. Anim. Sci. 63, $1649-1662$

Thomson A.B.R., 1979. Limitations of Michaelis-Menten kinetics in presence of intestinal unstirred layers. Amer. J. Physiol. 236, E701-E709

Thorens B., 1993. Facilitated glucose transporters in epithelial cells. Annu. Rev. Physiol. 55, 591-608

Tonroy B.R., Perry T.W., 1974. In vitro digestion of raw, roasted, and pressure-flaked corn. J. Dairy Sci. 57, 1508-1511

Turgeon O.A., Brink D.R., Britton, R.A., 1983. Corn particle size mixtures, roughage level and starch utilization in finishing steer diets. J. Anim. Sci. 57, 739-749

Waldo D.R., 1973. Extent and partition of cereal grain starch digestion in ruminants. J. Anim. Sci. 37, 1062-1074

Walker J.A., Harmon D.L., 1995. Influence of ruminal or abomasal starch hydrolysate infusion on pancreatic exocrine secretion and blood glucose and insulin concentrations in steers. J. Anim. Sci. $73,3766-3774$

Walker J.A., Krehbiel C.R., Harmon D.L., St Jean G., Croom W.J., Hagler, W.M., 1994. Effects of slaframine and 4-diphenylacetoxy-N-methylpiperidine methiodide (4DAMP) on pancreatic exocrine secretion in the bovine. Can. J. Physiol. Pharmacol. 72, 39-44

Williams A.G., Coleman G.S., 1997. The Rumen Protozoa, In: P.N. Hobson, C.S. Stewart (Editors). The Rumen Microbial Ecosystem. 2nd Edition. Blackie Academic and Professional, London, pp. $73-139$

Zhao F., Okine E.K., Cheeseman C.I., Shirazi-Beechey S.P., Kennelly J.J., 1998. Glucose transporter gene expression in lactating bovine gastrointestinal tract, J. Anim. Sci. 76, 2921-2929

Zinn R.A., 1990. Influence of flake density on the comparative feeding value of steam-flaked corn for feedlot cattle. J. Anim. Sci. 68, 767-775

\section{STRESZCZENIE}

\section{Trawienie skrobi u krów mlecznych i propozycja modelu mechanistycznego}

\section{Pożwaczowe trawienie skrobi i wchlanianie w jelicie cienkim}

Praca obejmuje przegląd literatury dotyczącej pożwaczowego trawienia skrobi i wchłaniania glukozy u krów mlecznych oraz przedstawia propozycję mechanistycznego modelu opisującego te procesy. Proces pożwaczowego trawienia skrobi ma szczególne znaczenie, gdy duża ilość nie rozłożonej w żwaczu skrobi przechodzi do dalszych odcinków przewodu pokarmowego. Trawienie skrobi i wchłanianie powstającej $w$ tym procesie glukozy może być ograniczone ilością wydzielanej w soku trzustkowym $\alpha$-amylazy jak też i dostepnością transporterów glukozy $w$ tkance jelita krów mlecznych. Znaczenie pożwaczowego trawienia skrobi jest dyskutowane w powiązaniu ze znaczeniem pochodzenia skrobi i sposobu jej obróbki technologicznej, jako istotnych czynników wpływających na jej pożwaczowe trawienie. Znaczenie procesów pożwaczowego trawienia skrobi i jelitowego wchłaniania zwiększa się wraz z ilością pobieranej przez zwierzęta skrobi. Omówiono również inne czynniki wpływające na przebieg procesu trawienia, pozwalające na interpretację danych uzyskanych $w$ doświadczeniach $\mathrm{i}$ brane pod uwagę $\mathrm{w}$ opracowaniu koncepcyjnego modelu trawie- 
nia skrobi. Przegląd rozpatruje w jakim stopniu pożwaczowe trawienie skrobi jest brane pod uwagę w istniejących modelach trawienia żwaczowego i omawia główne elementy modelu trawienia, który pozwalałby na dokładne obliczenie ilości opuszczającej żwacz nie strawionej skrobi i jej znaczenie w praktycznym żywieniu krów. Podczas gdy trawienie skrobi w żwaczu jest już uwzględniane w kilku opisanych w literaturze modelach, to pożwaczowe trawienie skrobi i wchłanianie glukozy jest jak dotąd w dużym stopniu ignorowane. Przedstawiony model jest schematem, na którym może być zbudowany przyszły model trawienia skrobi przez krowy mleczne. 